\title{
MUSLIM TOURIST SATISFACTION OF HALAL TOURISM IN LOMBOK
}

\section{KEPUASAN WISATAWAN MUSLIM PADA PARIWISATA HALAL DI LOMBOK}

\author{
F. Rahmiati1a; N.A. Othman²; M.A.P. Sunanti'3; \\ 1aFaculty of Business, President University, Jl Ki HajarDewantara, Jababeka Education \\ Park, Cikarang, Indonesia, e-mail: filda.rahmiati@president.ac.id \\ ${ }^{2}$ Faculty of Technology Management and Technopreneurship, Universiti Teknikal \\ Malaysia Melaka, Jl Hang Tuah Jaya, Durian Tunggal, Melaka, Malaysia, \\ e-mail: norfaridatul@utem.edu.my \\ ${ }^{3}$ Faculty of Business, President University, Jl Ki HajarDewantara, Jababeka Education \\ Park, Cikarang, Indonesia, e-mail: meilisaaudina@gmail.com
}

\begin{abstract}
The rising of Muslim population around the world creates the increasing demand for tourism in accordance with Islamic rules called as Halal Tourism. This study examined Lombok islands which have won an International Halal Destination Award in 2016. This study investigates Destination Image, Perceived Value and Islamic Value impact on Muslim Tourist Satisfaction of Halal Tourism in Lombok. This research used 110 respondents using non-probability sampling with convenience sampling and a survey through questionnaires. Data analysis procedures used in this study is Multiple Linear Regression. Based on Multiple Linear Regression, a result of Destination Image, Perceived Value, and Islamic Value were found to have the positive and significant impact on Muslim Tourist Satisfaction partially and simultaneously with $\mathrm{R}^{2}$ of 0.775 . It indicates that 77.5 persen of the variance in Muslim Tourist Satisfaction in Lombok influenced by Destination Image, Perceived Value, and Islamic Value. The recommendation is given to future study are used this three variables in other locations of halal tourism in Indonesia, therefore, it will create a sustainable halal tourism of Indonesia which create a competitive advantage in attracting tourist to visit Indonesia for Halal tourism purposes.
\end{abstract}

Keywords: Halal tourism, Destination Image, Perceived Value, Islamic Value, Tourist Satisfaction

\begin{abstract}
ABSTRAK
Meningkatnya populasi Muslim di seluruh dunia menciptakan peningkatan permintaan untuk pariwisata sesuai dengan aturan Islam yang disebut sebagai Pariwisata Halal. Studi ini meneliti pulau-pulau Lombok yang telah memenangkan Penghargaan Tujuan Halal Internasional pada tahun 2016. Penelitian ini menginvestigasi Gambar Tujuan, Nilai Persepsi dan Nilai Islam yang berdampak pada Kepuasan Wisatawan Muslim dari
\end{abstract}


Pariwisata Halal di Lombok. Penelitian ini menggunakan 110 responden dengan menggunakan non-probability sampling dengan convenience sampling dan survey melalui kuesioner. Prosedur analisis data yang digunakan dalam penelitian ini adalah Multiple Linear Regression. Berdasarkan Multiple Linear Regression, hasil dari Citra Tujuan, Nilai Persepsi, dan Nilai Islam ditemukan memiliki pengaruh positif dan signifikan terhadap Kepuasan Wisatawan Muslim secara parsial dan simultan dengan R2 sebesar 0,775. Ini menunjukkan bahwa 77,5\% dari varians dalam Kepuasan Wisatawan Muslim di Lombok dipengaruhi oleh Gambar Tujuan, Nilai Persepsi, dan Nilai Islam. Rekomendasi yang diberikan untuk studi masa depan digunakan ketiga variable ini di lokasi lain pariwisata halal di Indonesia. Oleh karena itu, akan menciptakan pariwisata halal berkelanjutan Indonesia yang menciptakan keunggulan kompetitif dalam menarik wisatawan untuk mengunjungi Indonesia untuk keperluan pariwisata halal.

Kata Kunci: Pariwisata Halal, Gambaran Destinasi, Nilai yang di rasakan, Nilai Islami, Kepuasan wisatawan

Rahmiati, Filda. 2018. Muslim Tourist Satisfaction of Halal Tourism In Lombok. Jurnal Syarikah 4 (2): 122-129.

\section{INTRODUCTIONS}

Islamic economy recently has a new phenomenon in the tourism industry which has contributed to world economic growth called Halal Tourism (Committee for Economic and Commercial Cooperation of The Organization of Islamic Cooperation, 2016; Enda, 2015; Jaelani, 2017; Rahman et al., 2017; Wingett et al., 2016). Halal tourism was the one of the largest and the most profitable industry in the global market (Enda, 2015; Rahman and Musa, 2017). Further, seeing big opportunities in this business creates countries that nonMuslim majority such as Japan, Australia, Thailand, Singapore, Taiwan, and New Zealand also created Halal tourism products (Battour and Ismail, 2015; Chookaew et al., 2015; Enda, 2015).
In 2012, Indonesia began to introduce some of their provinces as Halal Destination which launched in 2014 as one of the largest Halal Tourism market reinforced by the rapid of Halal Tourism products (Firdausi et al., 2017; Jaelani, 2017). Lombok as one of a city in West Nusa Tenggara (NTB) which 96, 78 percent of the population consist of Muslim (Central Agency on Statistics of NTB, 2017). The big potential of Lombok as Halal Tourism Destination has been approved in 2015 by The World Halal Tourism Awards was held in Abu Dhabi, Uni Emirate Arab. Lombok was awarded as the $1^{\text {st }}$ World's Best Halal Honeymoon Destination and the $1^{\text {st }}$ World's Best Halal Tourism Destination. Another two more awards were given in 2016 as The World's Best Halal Honeymoon Destination, and the $1^{\text {st }}$ World's Best Halal 
Tourism Destination (Alamsjah, 2016). The assessment of those awards was based on several points such as complete halal facilities in the tourist destination also the atmosphere of destination must be Muslim friendly tourism (Indonesia Ministry of Finance, 2016).

Those awards mentioned above may affect Lombok image globally. However, there are several problems spotted at Lombok that will be considered by the tourist. The crucial part is the health problem. The number of doctors in Lombok is currently under 70 people and still requires hundreds of doctors, pharmacists as well as nurses (Khalid, 2017; Supriadi, 2017) which would endanger the safety of the tourist. Another problem is lack of electricity and mobile phone signals. (Sompotan, 2012; Basir, 2016). This can disrupt the convenience of tourists. The next problem is a constraint in the field of transportation that also felt by the Head of Culture and Tourism of Central Lombok he is Mr. H.L. Moh. Putria. Difficulty in finding transportation, making tourists difficult to reach their lodging (Sompotan, 2012; Dulay, 2015). Lastly, Lombok has not set up separate places between men and women and also hard to find the worship facilities (Mulyono, 2016).

All of the above-mentioned affect tourist satisfaction (Devesa, et al., 2010; Žabkar, et al., 2010). Hence, based on previous studies, tourist satisfaction can be achieved through Destination Image, Perceived Value and Islamic Value (Artuğer, et al, 2013; Chen and Chen, 2010; Chi and Qu, 2008; Chiu, et al., 2016; Hashim et al., 2010; Ryu, et al., 2012; Sun, et al., 2013). Therefore, this study will use those variables as to measure Muslim Tourist Satisfaction of Halal Tourism in Lombok.

\section{LITERATURE REVIEW AND RESEARCH METHODS}

This study used quantitative method and questionnaire used as survey method and tested using SPSS for statistical calculation. The sampling design of this study used convenience sampling whereby the population of individuals who are advantageously accessible or available when it comes to take an interest and take part of this study (Dudovsky, 2016). Therefore, population of this study are domestic muslim tourists who visit Lombok by one of tour agent. Sample taken in this study based on Supranto (2010) stated that the number of respondents are five times the number of questions. Since the questionnaire consists of 22 questions, the number of respondents for this research is 110 respondents.

A questionnaire is a data collection technique that done by providing a set of written questions consisting of research variables that must be answered by the respondent(Kountur, 2009).The questionnaire spread to the number of samples. The questionnaire is divided into three sections: first section is filtering questions, second section is about demographic profile of respondents, and last questions comprise of independent variables (Destination Image, Perceived Value, and Islamic Value) and dependent variable of Muslim Tourist Satisfaction of Halal Tourism in Lombok. 
This study took demographic profile information based on the gender, age, past experience in Lombok, and length of stay. For section three (3) with total questions of 22 questions the respondent were asked to answer the agreement level that related to the variables chosen by using five points Likert scale rangingfrom strongly disagree to strongly agree.

The study applied reliability for measuring the questionnaire which is the indicators or variables or constructs whether the questionnaire is reliable or not(Ghozali, 2016). One of the most frequently used reliability coefficients is Cronbach alpha value. Sekaran and Bougie (2016) stated that Cronbach alpha greater than 0.60 is commonly accepted. Further, to test the hypothesis, multiple linear regressions will be used in this study.

Regression analysis is used for understanding the relationship between a variable and to predict the value of one variable based on another variable. On the other hand, Regression models used to test whether there is a relationship between variable is exist or not. Regression with more than one independent variable called multiple regressions, a condition when the research use two or more independent variables in a linear regression analysis (Ghozali, 2016).

Added, this study using t-test for analyzing independent variable (Destination Image, Perceived Value, and Islamic Value) positive significant on dependent variable (Muslim Tourist Satisfaction of Halal Tourism in Lombok) and using F-test to ascertain the positive significant of all independent variables positive significant on dependent variable
(Muslim Tourist Satisfaction of Halal Tourism in Lombok). Lastly, $\mathrm{R}^{2}$ is measured to see how many percentage of dependent variable explained by the independent variables jointly regress. This study using Adjusted $\mathrm{R}^{2}$ values as independent variables are more than two variables and range from 0 to 1 .

\section{RESEARCH RESULT AND DISCUSSION}

Table 1 illustrates the results of 110 respondents of the study. In terms of gender, the majority of respondents are males with $55.5 \%$ followed by females of $44.5 \%$. The highest percentage of age is $32.7 \%$ with age between $26-34$ years old, followed by more than 45 years old of $27.3 \%, 35-45$ years old of $26.4 \%$ and the last percentage is $13.6 \%$ of $16-25$ years old. More than half $(61.8 \%)$ are first-time tourist visit Lombok and the rest of $38.2 \%$ are repeated visitors. Last demographic respondent result is a length of stay. Majority of respondents are staying 4-6 days in Lombok with $44.5 \%$ followed by more than 6 days (of $30 \%$ ) and lastly, $24.5 \%$ are $1-3$ days.

Table 1: Demographic profile of respondents

\begin{tabular}{|l|l|l|l|}
\hline \multicolumn{2}{|c|}{ Characteristics } & N=110 & (\%) \\
\hline \multirow{3}{*}{ Gender } & Male & 61 & 55.5 \\
\cline { 2 - 4 } & Female & 49 & 44.5 \\
\hline \multirow{2}{*}{ Age } & $16-25$ years old & 15 & 13.6 \\
\cline { 2 - 4 } & 26-34 years old & 36 & 32.7 \\
\cline { 2 - 4 } & 35-45 years old & 29 & 26.4 \\
\cline { 2 - 4 } & $\begin{array}{l}\text { More than 45 } \\
\text { years old }\end{array}$ & 30 & 27.3 \\
\hline \multirow{2}{*}{$\begin{array}{l}\text { Past } \\
\text { experience }\end{array}$} & First-time visit & 68 & 61.8 \\
\hline \multirow{2}{*}{$\begin{array}{l}\text { Length of } \\
\text { stay }\end{array}$} & Repeated visit & 42 & 38.2 \\
\hline \multicolumn{2}{|l|}{$1-3$ days } & 27 & 24.5 \\
\hline & 4-6 days & 49 & 44.5 \\
\hline & More than 6 days & 34 & 30.0 \\
\hline
\end{tabular}


Reliability test aims to indicate the stability and the consistency of both independent variables and the dependent variable with the concept of the research. Hence, it is a tool for measuring the questionnaire which is the indicators or variables or construct. Questionnaire can be said as reliable if respondents' answer the questions consistently. In the table above, the results of Cronbach's alpha of each variable are reliable as the result of Cronbach's alpha greater than 0.60. Based on the result, all constructs are reliable and can be used for the next step show in Table 2.

Table 2: Reliability Test Result

\begin{tabular}{|c|c|c|c|}
\hline Construct & & $\begin{array}{c}\text { Cronbach's } \\
\text { Alpha }\end{array}$ & $\begin{array}{c}\mathrm{N} \text { of } \\
\text { items }\end{array}$ \\
\hline Destination Image & & .846 & 4 \\
\hline Perceived Value & & .740 & 9 \\
\hline Islamic Value & & .849 & 4 \\
\hline $\begin{array}{l}\text { Muslim } \\
\text { Satisfaction }\end{array}$ & Tourist & .891 & 5 \\
\hline
\end{tabular}

Table 3 shows the Multiple Linear Regression Result. Based on the table, by performing the multiple linear regressions, it found that the $\mathrm{R}^{2}$ for tourist satisfaction indicates 0.769 which shows that $76.9 \%$ of the variance in Muslim Tourist Satisfaction in Lombok influenced by Destination Image, Perceived Value, and Islamic Value. The analysis result found that all factors which influence tourist satisfaction partially as well as simultaneously are positive and significant. Destination Image has Positive and Significant on Muslim Tourist Satisfaction of Halal Tourism in Lombok ( $b=0.347, \mathrm{p}=.000)$. Therefore, $\mathrm{H}_{1}$ is accepted. This result is similar to Lita and Ma'ruf., (2015)that explained the factor that will gain a Tourist Satisfaction is Destination Image because with a good image in the global market makes a destination look more beautiful.

Next hypothesis also accepted $\left(\mathrm{H}_{2}\right)$ stated that Perceived Value has Positive and Significant on Muslim Tourist Satisfaction of Halal Tourism in Lombok $(b=0.260, \mathrm{p}=.000)$ similar result with a study of Putra et al (2016) demonstrated that perceived value is the important influences on the formation of tourist satisfaction. As perceived value is the starting point in the formation of attitudes for consumers and result in increasing the satisfaction.

For the third hypothesis stated Islamic Value has Positive and Significant on Muslim Tourist Satisfaction of Halal Tourism in Lombok $(b=0.368, \mathrm{p}=.000)$ is accepted $\left(\mathrm{H}_{3}\right)$. This result is similar to Luthfi (2018) that demonstrated that Islamic Value is influenced the tourist satisfaction. It is because the variable that needs by Halal Tourism in visiting some destination and must be fulfilled.

Lastly, the result of simultaneously, destination image, perceived value, and Islamic value have positive and simultaneous significant on Muslim tourist satisfaction $(p=.000)$. Therefore, hypothesis four $\left(\mathrm{H}_{4}\right)$ is accepted.

\begin{tabular}{|c|c|c|c|c|}
\hline Dependent & \multicolumn{4}{|c|}{ Muslim Tourist Satisfaction } \\
\hline \multirow{2}{*}{$\begin{array}{l}\text { Independent } \\
\text { variables }\end{array}$} & \multicolumn{4}{|c|}{ Destination Image } \\
\hline & \multicolumn{4}{|c|}{$\begin{array}{l}\text { Perceived Value } \\
\text { Islamic Value }\end{array}$} \\
\hline Multiple $R$ & \multicolumn{4}{|c|}{0.880} \\
\hline$R^{2}$ & \multicolumn{4}{|c|}{0.775} \\
\hline Adjusted $R^{2}$ & \multicolumn{4}{|c|}{0.769} \\
\hline Std Error & \multicolumn{4}{|c|}{1.33256} \\
\hline $\mathbf{F}$ & \multirow{2}{*}{\multicolumn{4}{|c|}{$\begin{array}{c}121.744 \text { Sig. } 0.000 \\
110\end{array}$}} \\
\hline $\mathbf{N}$ & & & & \\
\hline Model & $b$ & Beta & $\mathrm{t}$ & Sig. \\
\hline Constant & 1.855 & & 1.831 & .070 \\
\hline Destination Image & .347 & .376 & 4.371 & .000 \\
\hline Perceived Value & .260 & .346 & 7.348 & .000 \\
\hline
\end{tabular}




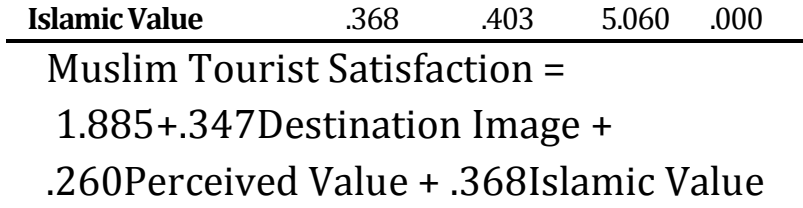

\section{CONCLUSION AND IMPLICATIONS}

Based on the results of research, Muslim Tourist Satisfaction of Halal Tourism in Lombok is positively significant influenced by Destination Image, Perceived Value, and Islamic Value with $76.9 \%$. In terms of Destination Image, by having a good image helped Lombok to be chosen as the Halal Destination. As perceived values by good quality, price, emotional, and social Lombok can satisfy it tourists. Islamic value, hence, eventually create the satisfaction of Muslim Tourist to Lombok. It is hope that Lombok can contribute in reaching the target of Indonesia Tourism by 20 million tourists arrival in 2020 . It is approved that satisfied tourist could lead to revisit as well as spreading positive word-of-mouth to prospective tourist.

As for recommendations, Lombok needs to maintain existing facilities, improve the infrastructures and related Muslims Tourist necessities as it create the competitive advantage of Halal Tourism in Lombok. Other recommendation is given to future studycould be used similar variables in other locations such as Nangroe Aceh Darussalam (NAD), West Sumatra, Banten, West Java, Central Java, East Java, South Sulawesi, etc. of halal tourism in Indonesia, therefore, it will create a sustainable halal tourism of Indonesia tourism which creates a competitive advantage for Indonesia in attracting tourist to visit Indonesia for Halal tourism purposes.

\section{REFERENCE}

Alamsjah, M.I. 2016. "Paparan Kementrian Pariwisata RI untuk KIDi ke-6 2016"September.

Artuğer, S., Çetinsöz, B. C., \& Kılıç, İ., 2013. The Effect of Destination Image on Destination Loyalty: An Application On Alanya. European Journal of Business and Management, 5(13), 2222-2839.

Basir, S., 2016. Lombok Masih Kekurangan Daya Listrik. Retrieved from

HTTP://ekonomi.kampungmedia.co m/2016/06/12/lombok-masihkekurangan-daya-listrik-14056

Battour, M., \& Ismail, M. N., 2015. Halal tourism: Concepts, practices, challenges, and future. Tourism Management Perspectives, 19, 150154.

https://doi.org/10.1016/j.tmp.2015 .12 .008

Central Agency on Statistics of Nusa Tenggara Barat., 2017. Percentage of Population by Regency / Municipality and Religions in Nusa Tenggara Barat Provinces 2016. Retrieved from http://ntb.bps.gp.id/statisticable/2 017/11/15/189/persentasependuduk -menurut-kabupatenKota-dan-agama-yang-dianut-diprovince-nusa-tenggara-barat2016.html.

Chen, C. F., \& Chen, F. S., 2010. Experience quality, perceived value, satisfaction and behavioral intentions for heritage tourists. Tourism 
Management, $\quad 31(1), \quad 29-35$. https://doi.org/10.1016/j.tourman. 2009.02.008

Chi, C. G., \& Qu, H., 2008. Examining the structural relationships of the destination image, tourist satisfaction and destination loyalty: An integrated approach. Tourism Management, 29, 624-636. https://doi.org/10.1016/j.tourman. 2007.06.007

Chiu, W., Zeng, S., \& Cheng, P. S. T., 2016. The influence of destination image and tourist satisfaction on tourist loyalty: a case study of Chinese tourists in Korea. International Journal of Culture, Tourism and Hospitality, 10(2), 223-234. https://doi.org/10.1108/IJCTHR07-2015-0080

Chookaew, S., Chanin, O., Charatarawat, J., Sriprasert, P., \& Nimpaya, S., 2015. Increasing Halal Tourism Potential at Andaman Gulf in Thailand for Muslim Country. Journal of Economics, Business and Management, 3(7), 739-741. https://doi.org/10.7763/JOEBM.20 15.V3.277

Committee for Economic and Commercial Cooperation of the Organization of Islamic Cooperation., 2016. Muslim Friendly Tourism: Understanding the Demand and Supply Sides In the OIC Member Countries. Muslim Friendly Tourism, (February), 1110.

Devesa, M., Laguna, M., \& Palacios, A., 2010. The role of motivation in visitor satisfaction: Empirical evidence in rural tourism. Tourism Management, 31(4), 547-552. https://doi.org/10.1016/j.tourman. 2009.06.006

Dudovskiy, J., 2016. The Ultimate Guide to Writing a Dissertation in Business Studies: A step-by-step Assistance. United States : researchmethodology.net, 2016.

Dulay, Z., 2015. Kekurangan dan kelebihan wisata di Lombok dan Raja Ampat part 1. Retrieved from http://zikridaulay.blogspot.co.id/20 $15 /$.

Enda, L. A., 2015. Laporan Akhir Kajian Pengembangan Wisata Syariah.

Firdausi, I., Marantika, S., Firdaus, Z. N., \& Sajidah, R., 2017. Lombok: Halal Tourism as a New Indonesia Tourism Strategy. International Conference on Humanities, 13-14.

Ghozali, I., 2016. Aplikasi Analisis Multivariate Dengan Program IBM SPSS 19. Semarang : Universitas Diponegoro.

Hashim, N. H., \& Kadir, S. L. S. A., 2010. The Effect of Corporate Image, Customer Perceived Value, Relationship Quality And Switching Intention Among Islamic Banking Customers In Malaysia. Business Management Quarterly Review, 1(4), 60-74.

Indonesia Ministry of Finance., 2016. Kementerian Keuangan. Retrieved April 10, 2018, from https://www.kemenkeu.go.id/publi kasi/siaran-pers-lama/menangkanwhta-world-halal-tourism-awarduntuk-pariwisata-ind

Jaelani, A., 2017. Halal Tourism Industry in Indonesia: Potential and Prospects. SSRN Electronic Journal, $7(3)$, 25-34. 
https://doi.org/10.2139/ssrn.2899 864

Khalid, F., 2017. Lombok Barat Kekurangan 210 Dokter. Retrieved from

https://mataram.antaranews.com/b erita/32558/lombok-Barat-

kekurangan-210-dokter.

Kountur, R., 2009. Metode Penelitian untuk Penulisan Skripsi dan Tesis, Edisi Revisi. Jakarta: PPM.

Lita, R. P., \& Ma'ruf., 2015. Relationship model among sport event image, destination image, and tourist satisfaction of Tour de Singkarak in West Sumatera. Journal of Economics, Business \& Accountancy Ventura, 18(1), 91-102. https://doi.org/10.14414/jebav.v1 $8 \mathrm{i} 1.386$

Luthfi, M., 2018. Pengaruh Islamic Attributes, Destination Attribute dan Quality Service terhadap Islamic Tourism Satisfaction Pantai Tiram Pariaman, 2.

Mulyono, K., 2016. Mengapa Wisata Halal untuk Lombok?. Retrieved from http://lombokinsider.com/generalnews/mengapa-wisata-halal-untuklombok/

Putra, E. H., Hati, S. R. H., \& Daryantic, S., 2016. Understanding Muslim Customer Satisfaction with Halal Destinations: The Effects of Traditional and Islamic Values. International Conference on Business and Economics, 167-175. https://doi.org/10.15405/epsbs.20 16.11.02.16

Rahman, M. K., \& Musa, S Z. G., 2017. What travel motivational factors influence
Muslim tourist towards MMITD? Journal of Islamic Marketing, 8(1).

Ryu, K., Lee, H., \& Kim, W. G., 2012. The influence of the quality of the physical environment, food, and service on restaurant image, customer perceived value, customer satisfaction, and behavioral intentions. International Journal of Contemporary Hospitality Management, 24(2), 200-223. https://doi.org/10.1108/09596111 211206141

Sekaran, U\& Bougie, R. 2010.Research Method for Business: A Skill Building Approach. New Jersey : wiley, 2010.

Sompotan, J., 2012. Tiga Kekurangan Pariwisata Lombok. Retrieved from https://lifestyle.okezone.com/read/ 2012/02/13/407/574625/tigakekurangan-pariwisata-lombok.

Sun, X., Chi, C. G., \& Xu, H., 2013. Developing Destination Loyalty: The Case of Hainan. Annals of Tourism Research, 43, 547-577. https://doi.org/10.1016/j.annals.20 13.04.006

Supranto, J., 2010. Statistik Teori dan Aplikasi. Jakarta : UI Press, 2010.

Supriadi, W., 2017. Loteng Kekurangan Perawat dan Bidan. Retrieved from https://Radarlombok.co.id/lotengkekurangan-perawat-dan bidan.html.

Žabkar, V., Brenčič, M. M., \& Dmitrović, T., 2010. Modelling perceived quality, visitor satisfaction and behavioural intentions at the destination level. Tourism Management, 31(4), 537546.

https://doi.org/10.1016/j.tourman. 2009.06.005 